\title{
Species are a measure of man's freedom: reflections after writing a Red Data Book on African birds
}

\author{
N.J. Collar
}

The broad vision of the new environmentalist, who seeks to conserve the world's ecosystems for the sake of the human species as well as wildlife, has much to commend it. Beside it, the traditional conservationist's approach, aiming to conserve wildlife for its own sake, seems outmoded. The development of the concept of ecosystem management, however, has been accompanied by other shifts in emphasis. Among them is the idea of wildlife as an economic asset, paying for its own conservation by providing, for example, tourist revenue and pharmaceuticals. This development may seem to be the fulfilment of the dream of those who want to 'sell' conservation to those with power over the environment. The author, who has recently completed writing the ICBP/IUCN Red Data Book on African birds, offers a personal view of where the new trend may be leading many of the threatened species of the earth.

Africa, once so rich and fertile, is in deep crisis. Today, most of its nations are riven by debt, strife and decay, its peoples are hungry for land, fuel and food. In some countries the human population is multiplying at terrifying rates, in others it is dying at terrifying rates. Nothing seems properly under control; such stability as there is evidently depends on unsustainable conditions of exploitation. The ordinary citizens of the developed world look on in confusion and anguish, waiting for an explanation that fits, wishing for an intervention that works, and willing at least to pay if only to deport those starving children from their consciences and the after-dinner television programmes. The welfare of the peoples of Africa has never been in sharper focus than it is now.

Species: a measure of man's freedom

\section{Case for conservation in question}

Wildlife conservationists must regard the current drought in Africa as a double disaster, for not only has it wrought new ecological havoc but, through its appalling consequences for human beings, it threatens to erode much of the confidence with which the case for wildlife conservation can be made. As they lobby to secure a patch of forest here, an area of marsh or a tract of grassland there, commonly in the name of the animal and plant species that live in them, the conservationists' position must to many people appear indefensible. How can anyone, at this moment in history, expect Africa to save its wildlife? Who in their right minds thinks there should be international aid for the continent's birds?

Questions requiring conservation to justify itself have been posed-mostly by conservationists anxious to demonstrate their urgent need for support-with increasing frequency in the past twenty years. Some fairly comprehensive answers have been attempted; the general response can be identified simply from the history of the international conservation movement during this time, and particularly in the past decade. The crisis in Africa, which many perhaps would see as the first really serious manifestation of an ever-intensifying global crisis, forces these questions on us afresh; and, although a first answer might be that the area of the major human crisis in the continent is generally not one where major wildlife conservation initiatives are needed, it is important that the final answer-the one that must stand irrespective of the geography of human crisis-be given with authority and without flinching. 


\section{Emergence of new justifications}

The rationalizations for species conservation are many. The difficulty these rationalizations have encountered is that the species in need of conservation are also many, far too many. In the past ten years, human pressure on the environment has forced hundreds and possibly thousands of species to the brink of extinction. The problem has become one of scale. Thus it is that the most distinctive trends in conservation ideology over this period have been (first) the growth of the recognition that ecosystem (as opposed to mere habitat) management has to replace species protection as the primary goal, (second) the perception that national parks and equivalent protected areas are a primary means of achieving this goal, and (third and most important) the emergence of the necessity to justify this and all other means in conservation by reference to the economic benefits they bestow.

\section{Importance of the environmentalist}

These new emphases have been closely related to the growth in influence of the 'environmentalist', one whose concern is the general maintenance of ecosystems for the sake not only of their constituent wildlife but also of mankind itself. That influence is not yet strong enough to wring the concession that it is he or she, the environmentalist, who holds the keys that will secure the future of life, not just in Africa but everywhere on this planet; but the truth of this claim is dawning, and, to be persuaded of it, one need do no more than recognize that the crisis in Africa is first and foremost an environmental crisis. Whatever its social, economic and political determinants, its ultimate manifestation concerns the disintegration of the natural environment, and its ultimate resolution-if there is to be onemust involve the reintegration of man into that environment. Who else but the environmentalist is in any position to provide both the detailed knowledge and the genuine care to make such a reintegration possible?

All these developments-the modern ascendancy of environmentalist thought in conservation, the concentration on ecosystem-oriented planning, the promotion of national parks and the 16 profit motive-are attempts to introduce realism into a situation where the only thing in shorter supply than money is time. The 'new realist' adoption of principles of human welfare transcends the traditional conservationist approach (which seeks the preservation of wildlife very much for its own sake), and serves to indicate how the traditional (or at least traditionally perceived) function of conservation can today be rejected as an outmoded, inadequate and irrelevant response to the ever-intensifying conflict between man and nature. The latter may be seen as seeking to end the conflict by interdict and, if necessary, by force, and through the demarcation of parks and reserves as no-go areas; the environmentalist or 'new realist' approach, by contrast, lies in reconciliation through the demonstration of mutual benefit.

\section{Wildlife must pay}

The environmental crisis in Africa, and indeed in many other parts of the developing world, has only served to confirm the practical importance of these shifts of emphasis. Economic arguments in particular have become a crucial element in the marketing of wildlife conservation; the currency and respectability of such terms as 'genetic material', 'renewable resources' and 'sustainable development' are universal. Indeed, 'conservation for development' has become the central theme of modern strategy. Again and again the case is made and the experience gained that wildlife must pay-and be seen to pay-if it is to survive. The Parc des Volcans in Rwanda now 'pays' because its famous gorillas pull the tourists by the plane-full; wildlife-ranching and gamehunting in southern Africa now 'pay' and provide every incentive to maintain the environmental status quo; many of Africa's mountain forests 'pay' by stabilizing soils and holding water. This particular development is doubtless as necessary as it was inevitable, and will provide the basis for many new and urgently needed achievements in conservation.

The document perhaps most central to the rationalization of the new realism is the World Conservation Strategy (IUCN, 1980). The case it makes out for saving species is unequivocally utilitarian: 'the preservation of genetic diversity is

Oryx Vol 20 No 1, January 1986 
both a matter of insurance and investmentnecessary to sustain and improve agricultural, forestry and fisheries production, to keep open future options, as a buffer against harmful environmental change, and as the raw material for much scientific and industrial innovationand as a matter of moral principle'. This 'moral principle' proves to be no more than that 'we cannot predict what species may become useful to us', many 'that seem dispensable' perhaps one day proving able to provide 'important products, such as pharmaceuticals' or to be 'vital parts of life-support systems on which we depend'.

\section{The dangers of utilitarianism}

On the face of it, the new realism of the past decade or so certainly appears to be a cogently self-justifying response to the multiplying exigencies in modern wildlife conservation. However, pick up any international Red Data Book and, from even a brief skim, see just how many threatened species and attendant problems there are, and one is immediately flooded with doubt. What can one do for the organisms with patently no economic value, or for those which (like a coal-mine) will one day lose theirs? What will be the fate of all those species for which no national park or other protected area is possible? How can one get the message across that they might just some day be of use to us? Are they vital parts of an ecosystem? Do we simply write them off if they are not?

Although the World Conservation Strategy's last line of defence, the 'potential utility' argument, appears theoretically sound, it invites calculated risk and is wretched proof against the case for a known utility. A programme to improve the efficiency of land-utilization through the removal of trees, right in the middle of the Ethiopian bushcrow's tiny range, would scarcely be halted through considerations (alone) of what benefits the bush-crow might conceivably one day bestow upon us. A similar deference to posterity is no more likely to shift the refugee camp now set up within the even tinier range of the Somali longclawed lark. That Rugezi and Kamiranzovu Swamps in Rwanda are the two most important sites in the world for Grauer's swamp warbler will Species: a measure of man's freedom hardly deflect current plans to drain them (for tea plantations and gold prospecting respectively). Moreover, the history of extinctions, both local and global, tells us quite clearly that no one species is likely to be so vital to our 'life-support systems' that we could not survive perfectly well without it. Who is going to claim or be able to show that the Ethiopian bush-crow is an essential component of the 'life-support system' that is a belt of acacia in southern Ethiopia? Who will argue that the extinction of the Seychelles magpie-robin on all but one of the granitic Seychelles has started those islands on a relentless spiral downwards to degradation?

The fundamental problem with any case for species conservation built round principles of utility and economic value is that it is subject to confutation, or at least circumvention, by another case offering greater and/or more immediate utility and economic value. An economic value is a relative value; and relative values, like supply and demand, are constantly changing. If wildlife is always and only to be judged as a relative value, it can never achieve a stable, enduring security. The great strength of the new realism in conservation - the promotion of nature as materially useful to man's development-is thus also its greatest weakness, since this approach provides such poor insurance for the species, populations and habitats that appear surplus or indeed obstructive to the 'real' interests of the state and its people.

\section{Is 'packaged nature' the answer?}

We are deep in a dilemma. A hard-line advocate of the new realism might attempt to resolve it by claiming that some life is better than no life, and no life is what will remain if he cannot make himself heard above the babble about elephants, African violets, and birds. A hard-line traditional conservationist might reply that no life would be preferable to a planet laid out like a supermarket with nature in well-packaged, sterilized, bite-size portions. Nevertheless, there seems to be a relatively simple formulation, which, by recognizing the common spring of feeling for conservation on which both factions draw, may yet provide not only a better balance of their interests but also the 
basis for a much-needed reconciliation between them (after all, the same organizations that back the World Conservation Strategy back the Red Data Books).

\section{Feelings ignored}

The fault ultimately to be found with the new realism in its valuation of wildlife is that it totally fails to speak on behalf of the deepest feelings of people-including the people of developing countries-about the natural world. People do not all support conservation for its economic returns or its usefulness; huge numbers do so because they have a deeper, less obviously rational and therefore far less easily expressible conviction about the necessity of safeguarding wildlife. Myers (1979) notes that some 75 per cent of Africans, 85 per cent of Japanese, and 94 per cent of Latin Americans are reported to want more done to conserve wildlife and threatened species, and that 68 million households in the USA spend 500 million dollars per year feeding backyard birds. Love of nature, the fascination of animals, awe of wilderness, whatever it gets called, there lies within a vast proportion of humankind a powerful, positive feeling for the importance of the value of wildlife, not in relative terms but in absolute terms. It is the feeling that lies at the heart of all measures, laws and conventions that try to protect wildlife. It is not to be dismissed as the luxury of the affluent westerner; it is, after all, the declared basis of Tanzania's system of national parks, and it can only be what has motivated the Ugandans to maintain and even expand their protected area network during these last ten years of bankruptcy.

\section{A fundamental freedom}

It is, in its complete form, more than sentiment, more than aesthetic response (though it is also these things): it is a feeling for basic freedom, the freedom both of the wildlife-however unserviceable to man - to exist, and of every man to know it exists (a more fundamental human freedom than that of experiencing its existence at first hand): every species's death, to borrow John Donne, diminishes me, and mass extinction spells the death of the mind, the death of the imagination. The immeasurable diversity of wildlife is one of the richest sources of curiosity, stimulus and emotional satisfaction we possess: we cannot value this wealth in dollars, and we cannot calculate its power in terms of utility.

So if the environmentalist, the new realist, holds the keys to the future of life on this planet, the traditional conservationist holds the keys to the quality that life will have. If wildlife conservation must, in the main, continue to be marketed in terms of its utility and returns, a movement is now also needed to establish the principles that all species, not merely man, have absolute values (values to which we commit ourselves to the maximum of our capacity), and that all men have the right to the freedom that the existence of all species confers. This formulation might be misinterpreted as arrogance, a type of intellectual imperialism, but the contrary is the case: it is actually an attempt to give shape and force to the mass feelings that rise against the (culturally no less than ecologically) destructive arroganceimperialism, even-of much modern development. It seeks not to undermine the new realist strategy, but rather to underpin it with a greater honesty. If, by interposing a new 'right', it appears to restrict a man's freedom and threaten his right to live, it becomes a challenge to the world community to find a solution that honours both rights; and if it does this, then it commits the world to investigating and understanding the true and only means by which the world itself can ultimately be saved, which is by living in an ecologically sound way.

\section{In search of absolute standards}

Absolute value for species has been rejected by Myers (1979), who insists that 'no value . . . not even human life ... is considered by society to be absolute'. However, many individuals, institutions and governments evidently act as if certain values, and notably human life, were of absolute importance: the Hippocratic oath and the commandment not to kill are two obvious examples of society seeking absolute standards in the regulation of its affairs, the great majority of people accepting that such standards or values provide for their fundamental freedom and rights. Whether species can or should possess absolute value is a matter for debate, but their best hope of

Oryx Vol 20 No 1, January 1986 
survival may yet lie in international agreement as if they do. De Klemm's (1984) view that a new world treaty on species conservation could and should function on the revenue from economically profitable species lowned by the community of nations) introduces a needless element of risk. There is no point in pretending the world can only afford to work a treaty that way: billion dollar space projects and defence budgets tell a different story.

\section{Sacrificing species gives no long-term benefit}

There is a flipside of the view that environmentalists hold the keys to our planet's future life. If, in capitulation to man's free use of his environment as part of his 'right to live', traditional conservationists were to abandon wildlife and put their paltry financial resources into economic development of the type now seemingly globally practised (i.e. unrestricted by ecological principles), the resulting sacrifice of species would have not the slightest long-term benefit, would do no more than postpone (and in some cases actually advance) the day when starvation and ruin returned. The conservation of species must therefore be seen not merely as the defence of a right and a freedom in itself, but as a model for many virtues, not least the management of the environment as the comerstone of all economic development. It is not a pursuit that can be put off until the crisis in Africa is over; it is something that needs to be both seen and done as part of the resolution of that crisis. The Red Data Books, guardians of our freedom, make a good place to start.

\section{Acknowledgments}

I am most grateful to my friends the staff of the ICBP International Secretariat and of the IUCN Conservation Monitoring Centre, also to T. M. Caro and A. C. Carter, for their comments on and discussions of this essay in draft. The views it expresses are, I should stress, entirely personal.

\section{References}

IUCN. 1980. World Conservation Strategy. International Union for Conservation of Nature and Natural Resources. Gland, Switzerland.

de Klemm, C. 1984. Protecting wild genetic resources for the future: the need for a world treaty. In National Parks, Conservation, and Development: The Role of Protected Areas in Sustaining Society (Eds J. A. McNeely and K. R. Miller), pp. 661-666. Smithsonian Institution Press, Washington DC.

Myers, N. 1979. The Sinking Ark. Pergamon Press, Oxford.

N. J. Collar, International Council for Bird Preservation, 219c Huntingdon Road, Cambridge CB3 ODL, UK.

\section{Oryx: announcements and requests}

The Society has renewed its publishing agreement with Blackwell Scientific Publications Ltd, which was undertaken for an initial period of three years in 1983. With the renewed agreement comes an increase in the number of Oryx pages-68 in each issue rather than 64 . We are also pleased to announce improvements in the publishing schedule, which mean that the news section of Oryx will be more up-to-date than has been possible in the past. Contributions for the 'News and views' and 'Briefly' sections are welcomed and should reach the Editor by:

24 January 1986 for the April issue

25 April 1986 for the July issue

28 July 1986 for the October issue

Species: a measure of man's freedom
22 October 1986 for the January 1987 issue.

The sporadic appearance of the Letters page is largely due to a dearth of contributions, and the Editor invites more of these, especially those of fewer than 300 words.

The move to new offices has provided us with the space to begin to build a picture library. The Editor is in great need of suitable illustrative material for the pages of Oryx-especially in the final stages of preparing each issue. If you have any suitable black-and-white or colour photographs or transparencies that you could donate to the collection they would be most gratefully received. 